\title{
NEUROPROTECTION, EXCITOTOXICICITY AND NMDA ANTAGONISTS
}

\author{
RUBENS JOSÉ GAGLIARDI*
}

\begin{abstract}
Purpose - To analyze the main aspects of neuroprotection and excitotoxicity. Discussion - This is a significant theory on the pathophysiology of cerebral ischemia; it is based on the release of excitatory aminoacid (EAA), mainly glutamate. The sequence starts with a decrease of the blood flow and ends in neuronal death. The main stages of this reaction are herein presented and discussed. An in depth study of the effects of the excessive intracellular calcium is undertaken. Neuroprotectors (NP) are a group of drugs that reduce the excitotoxicity, opposing the excessive release of EAA and its intracellular effects. Neuroprotectors represent a rational approach to stroke treatment and offer a number of potential advantages. They prevent or limit ischemia-induced damage. Conclusion -There are many experimental and clinical NP trials. A minimum of 800 trials are currently under study worldwide. The most important NP subgroups are: N-methyl D-aspartate (NMDA) antagonists, gamma-amino butyric acid (GABA) agonists, amino-hydroxy-methyl-isoxalone propionic acid (AMPA) antagonists, reducers of intracellular $\mathrm{Ca}^{++}$inhibitors of nitric oxide modulation pathway free radicals scavengers, sodium channel antagonists, glutamate release inhibitor, growth factors, hypothermia and potassium channel activators.
\end{abstract}

KEY WORDS: neuroprotection, excitotoxicity, NMDA antagonists, stroke.

\section{Neuroproteção, excitotoxicidade e antagonistas do NMDA}

RESUMO - Propósito - Analisar importantes aspectos da neuroproteção e da excitotoxicidade. Discussão Excitotoxicidade é teoria que explica os mecanismos básicos da fisiopatologia da isquemia cerebral; é baseada na liberação excessiva de amino-ácidos excitatórios (AAE), principalmente o glutamato. A sequência se inicia com o decréscimo do fluxo sanguíneo cerebral e termina com a morte neuronal. Os principais aspectos desta cadeia de reações são apresentados e discutidos. Os efeitos do excesso de cálcio intracelular são analisados. Neuroprotetores (NP) são um grupo de drogas que reduzem a excitotoxicidade combatendo a excessiva liberação de AAE e os seus efeitos intracelulares. NP representam uma perspectiva racional para o tratamento do acidente vascular cerebral; previnem ou limitam o dano isquêmico. Há muitos ensaios, experimentais e clínicos, avaliando os NP. Conclusões - Um mínimo de 800 ensaios estão atualmente em andamento por todo o mundo. Os principais NP são analisados baseados no seu local de ação. Os principais grupos de NP são: antagonistas do receptor Nmetil D-aspartato (NMDA), agonistas do ácido gama amino butirico (GABA), antagonistas do receptor ácido amino hidróxido metil propionico (AMPA), redutores da mobilização do cálcio intracelular, inibidores das vias metabólicas do óxido nítrico, removedores de radicais livres, antagonistas de receptores de canais de sódio, inibidores da liberação do glutamato, fatores de crescimento e ativadores de receptores de canais de potássio.

PALAVRAS-CHAVE: neuroproteção, excitotoxicidade, antagonistas NMDA, acidente vascular cerebral.

Excitotoxicity is an important and well accepted theory ${ }^{1-4}$ proposed by Olney in $1971^{5}$ to explain the pathophysiology of brain ischemia. It consists in explaining the basic mechanism of cellular lesion after cerebral ischemia. Excitotoxicity is based on the release of excitatory aminoacid (EAA), mainly glutamate. The sequence starts with a decrease in cerebral blood flow (Fig 1).

Faculdade de Ciências Médicas da Santa Casa de São Paulo, Departamento de Medicina, Disciplina de Neurologia: *Professor-Adjunto, responsável pelo Setor de Doenças Cerebrovasculares. Aceite: 25-fevereiro-2000.

Dr. Rubens José Gagliardi - Av. Angélica 916/305 - 01228-000 São Paulo SP - Brasil. Fax 118261288. E:mail: rubensjg@ apm.org.br 
Aminoacid glutamate plays an important role in excitotoxicity ${ }^{3,4,6}$. A large number of studies have shown an increase in concentration of glutamate after cerebral ischemia. The sequence starts with depletion of energy phosphates, which produces neuronal depolarization due to failure of the ionic pump with the consequent increase in the extracellular potassium concentration. This event leads to a release of glutamate. ATP-dependent re-uptake mechanisms may contribute to glutamateinduced brain injury as well. The duration of the EAA release in human beings is unknown and this time period could determine the precise therapeutic window. The increase of EAA concentrations in experimental models is transient, lasting from 1 to 2 hours $^{7}$. In humans this elevation has been observed up to 4 days in patients with prolonged overall post-traumatic ischemic brain damage ${ }^{8}$.

The glutamate acts mainly in four receptors, divided in two groups: a- ionotrophic receptors (related to ions action): NMDA, amino-hydroxy-methyl-isoxalone propionic acid (AMPA), kainat (AMPA and kainat are known as non-NMDA receptors); b- methabotrophic.

The NMDA is the most important and the most studied receptor. It is related mainly to $\mathrm{Ca}^{++}$; the others are related mainly to $\mathrm{Na}^{+}$. Activation of the NMDA receptor to a large extent mediates the excitotoxicity and neuronal damage after ischemia; it is the most complex receptor. Besides glutamate, the aminoacid glycine also stimulates this receptor. Glycine is a co-agonist of the receptor-channel complex.

The factor responsible for determining the degree of ischemia in a given area of the brain is the number of NMDA receptors present in that area. The higher the concentration of NMDA in a specific area, for ex. CA1 area of the hipocampus, the more severe the ischemia will be, or vice-versa ${ }^{9}$.

Glutamate acts in about $30 \%$ of synapses in central nervous system (CNS), it is kept in specific vesicles and it is released in little doses that take over the receptors for 1 or $2 \mathrm{mseg}$ and then are metabolized by specific enzymes 9 . The glutamate opens the receptor dependent channel and then a large quantity of $\mathrm{Ca}^{++}$enters inside the cell. The excess of $\mathrm{Ca}^{++}$is highly toxic for the cells. Under normal conditions the intracellular $\mathrm{Ca}^{++}$level is stable and low, around 10000 times lower than the extracellular level. Besides $\mathrm{Ca}^{++}, \mathrm{Na}^{+}$also inflows and this further imbalances the cellular ionic levels. This leads to an increase of cerebral edema. The excess of $\left[\mathrm{Ca}^{++}\right]$stimulates a sequence of

cessation or decrease of $\mathrm{CBF}$

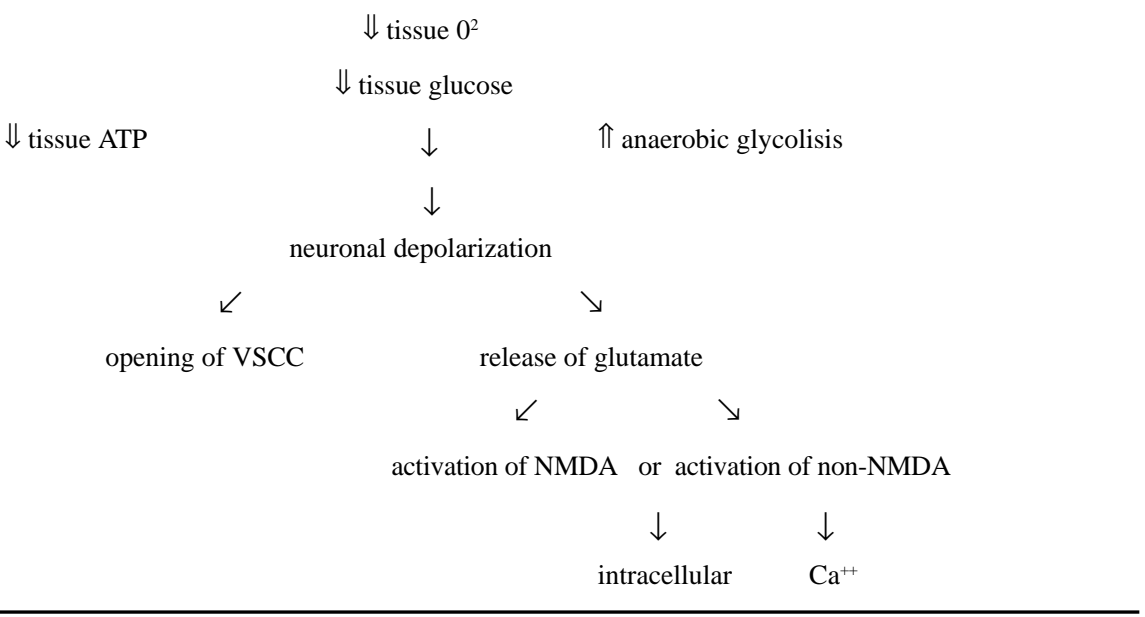

Fig 1. Excitotoxicity sequence.

$C B F$, cerebral blood flow; VSCC, voltage sensitive calcium channel; NMDA, receptor n-methyl d-aspartate. 
toxic enzymatic reactions and leads to cell death. In short, the main enzymatic reactions can be described as ${ }^{1,6,9-11}$ :

a. Damage of oxidative phosphorylation, lowering function and energy production by the mitochondria.

b. Activation of phospholipases that act on the phospholipids and contributes to the destruction of neuronal membranes and brain vascular endothelium, through a mechanism called enzymatic lipid peroxidation (the non enzymatic lipid peroxidation is of another kind performed by free radicals). The excess of arachidonic acid will lead to a biochemical sequential process, called arachidonic cascade with a final production of prostaglandins (thromboxane $\mathrm{A}_{2}$ and prostacyclin) and leucotriens, mainly thromboxane, which has a vasoconstrictive property

c. Activation of proteases that play an important role in the production of free radicals. $\mathrm{Ca}^{++}$ activates the protease, which on its turn changes dehydrogenasexanthine into oxidase xanthine, an important enzyme in the production of free radicals, like superoxide and -hydroxyl. The brain is particularly sensitive to the action of free radicals because it lacks normal scavengers and contains a large quantity of iron, an important coenzyme in this reaction. The free radical acts in the membrane phospholipid breaks the membranes and destroys the cell.

d. Activation of nitric oxide synthase (NOS). $\mathrm{Ca}^{++}$stimulates NOS and consequently increases the nitric oxide (NO) concentration. Over/production of NO from excessive or inappropriate stimulation of nNOS seems to mediate a major component of excitotoxicity damage. NO is one of the factors that mediates the excitotoxicity, producing free radicals. NO binds with superoxide to produce peroxinitrite, which in water solution spontaneously changes into the hydroxyl radical. This free radical unchains the lipid peroxidation. The NO has also played a role in the liberation of glutamate responsible for the fact that the NO formed leaves the neuronal cell, goes to the presynaptic space and releases glutamate inside the pre-synaptic cells. There are different kinds of NO, according to the specific form of NOS. There are three important isoforms of NOS: nNOS (type I), iNOS (type I), eNOS (type III) Pharmacological and genetic approaches have significantly improved our knowledge regarding the role of NO and the different NOS isoforms in cerebral ischemia. The $\mathrm{nNO}$ and iNO play key roles in degeneration, while eNOS plays a prominent role in maintaining cerebral blood flow and preventing neuronal injury. The excessive production of NO from the activation of nNOS (neuronal NOS) is related to the production of free radicals which is dangerous. It leads to ischemic neuronal damage; it is neurotoxic. The NO production from the iNOS immune NO) is related to the delayed ischemic process. The NO production from eNOS (endothelium NO) is related to the production of endothelium derived relaxing factor, has a vasodilator function and is a protective factor in ischemic events because it maintains the regional cerebral blood flow. The iNO is not detectable in healthy tissue; under pathological conditions iNO can be observed in most tissues, including neurons, astrocytes and endothelial cells. It is detectable 12 hours after onset of ischemia and has its peak 48 hours later.

e. Other important action of the excess of $\mathrm{Ca}^{++}$inside the neuronal cells, is its role in protein kinase $\mathrm{C}$ (PKC). In a normal situation PKC remains inactive in the cytosol but in the presence of excessive $\mathrm{Ca}^{++}$it goes to the neuronal membrane and it is activated by diacylglycerol and phosphatydylserin, then produces protein phosphorylation responsible for mechanisms of extrusion of $\mathrm{Ca}^{++}$. PKC acts also by rising the post synaptic sensibility to glutamate.

\section{NMDA Antagonists and Neuroprotection}

Neuroprotectors (NP) comprise a new group of drugs that reduce excitotoxicity, resisting the excess release of AAE and its intracellular effects. Neuroprotectors represent a rational approach to stroke treatment and offer a number of potential advantages. They prevent or limit ischemia-induced damage, could reduce infarction size and mortality and the functional outcome can be improved. Moreover, because neuroprotective treatment is not expected to affect bleeding, it could be used in all patients with suspected stroke, without the need of confirming the diagnosis of ischemic stroke. 
Although the prospects for the use of NP have been promissory, there is no convincing clinical evidence that any neuroprotective drug is effective in either reducing size of infarction or improving the overall outcome.

Neuroprotection intends to interrupt the pathological cascade that occurs during the ischemic process. It can also limit or stop the progressive depression, other important mechanism of aggression in ischemia ${ }^{12}$. There are important limitations for the reasonable use of these drugs: short time (therapeutic window) necessary to introduce the drug; treatment should be started a few hours after the onset of symptoms; difficulty to reach the ischemic site; strong side-effects, mainly psychotic, renal, blood pressure disorders, vacuolization; trials have failure to demonstrate any effectiveness of these agents ${ }^{13,14}$.

There are many trials studying these sequences. We can analyze the main items based on neuroprotective action:

a. NMDA antagonists - The NMDA receptor is a complex structure, with binding sites for divalent cations, polyamines and glycine, in addition to the ligand-binding site. Glutamate is the main agonist; glycine and polyamide are co-agonists of the NMDA receptor-channel complex. Antagonists binding to each of these sites have been developed and shown to have neuroprotective effects in animal models $\mathrm{s}^{1,2,4,6,15}$.

Competitive and non-competitive are the two kinds of NMDA antagonists.

The competitive ones compete directly against the glutamate; weakly cross the hematoencephalic barrier, but have high specificity and potency. The non-competitive ones act in the membrane of specific NMDA places and prevent the $\mathrm{Ca}^{++}$influx. They easily cross the blood-brain barrier $^{3,4,6}$. The main examples of these drugs are: dozocyilpin (MK 801), selfotel, cerestat, dextrometorfan. These agents seem to cause similar adverse effects regardless of their pharmacological action. Low doses are associated with altered sensory perception, dysphoria, nystagmus and hypotension, while higher doses may cause psychological adverse events such as excitement, paranoia and hallucinations; also severe motor retardation, leading ultimately to catatonia, which may occur with the highest doses ${ }^{1-4,6,15}$. Milder adverse effects have been noticed with cerestat, a non-competitive NMDA antagonist.

The glycine and polyamide sites on NMDA receptor complex offer a therapeutic target for acute focal ischemia, potentially devoid of most side effects associated with competitive and noncompetitive NMDA-antagonists. Glycine and polyamide-sites antagonists do not seem to be associated with psychological adverse events or vacuolization ${ }^{3,4}$. The main drugs in this sub-group are eliprodil and felbamate. Eliprodil is a modulator of polyamide site, it is at phase III of clinical research.

b. GABA agonists - While glutamate is a primary EAA in the brain, GABA is the most important inhibitory amino-acid. The potential action of GABA may reverse the toxic effects of glutamate through hyper-polarization of the neuronal membrane. A GABA agonist chlomethiazole has been found to reduce infarction size in a variety of stroke models. This approach is at phase III of research ${ }^{2-4,16}$.

c. AMPA antagonists - This is another possibility of action in neuroprotection, as AMPA also plays an important role in the rising of $\mathrm{Ca}^{++}$inside the cells. The most studied drug in this group is the NBQX, but unfortunately this drug is very nephrotoxic and clinical studies not optimistic ${ }^{3,4,16}$.

d. To reduce intracellular $\mathrm{Ca}^{++}$mobilization is other possibility to oppose excitotoxicity. Some drugs have been studied ${ }^{3,4}$ : GM-1, that inhibits the translocation of CPK; dantrilene sodium; some drugs that inhibit $\mathrm{Ca}^{++}$dependent enzymes (AT 877, under study).

e. Inhibitors of the pathways of NO modulation - Selective inhibition of nNOS inhibiting the specific production of toxic NO can offer a protection to neuronal tissues during the stroke. The NO made from nNOS plays an important role in the production of free radicals and its selective inhibition brings good results. 7-nitroindazole is still under clinical studies; it inhibits the nNOS and has no action on eNOS. Genetic deletion of nNOS also conferred dramatic resistance to focal ischemic 
injury $3,4,10,12,15,17$. Lubeluzole inhibits the production of the NO pathways and also helps preventing the increase of extracellular glutamate in the penumbra and in the normalization of excitability of neurons in this area. Lubeluzole has caused few side effects and phase II and III ${ }^{12}$.

f. Free radicals scavengers - Well-known free radical scavengers like tocopherol, selenium, b-carotene, have little action on neuronal tissue during ischemic processes . Tirilazad is a new scavenger under clinical study; the initial results had shown to be quite interesting ${ }^{3,4}$.

g. Sodium channel antagonists - $\mathrm{Na}^{+}$plays also a role in the ischemic process; the inhibition of pre-synaptic sodium channels, leads to a neuronal membrane stabilization which in turn, leads to the inhibition of pre-synaptic glutamate release and may be useful in stroke $e^{3,15,16,17}$. Some drugs, like a number of anti-epileptics, have this property: lamotrigine, phenytoin, fos-phenytoin, riluzole, lifarizine (under clinical tests).

h. Glutamate release inhibitors - Another strategy which can be used in neuroprotection. Several studies are under way with different drugs with inconclusive results ${ }^{12,18-21}$ : Omega-canotoxins; synthetic toxin SNX-111, has an important side-effect; it blocks adrenaline release leading to severe hypotension; nalmepene (opioid receptor antagonist); dexamethasone has an important side-effect in this issue, because it can increase the glutamate release or decrease glutamate re-uptake ${ }^{20}$.

i. Growth factors - Some growth factors might have a neuroprotection function. Angiogenic factors might be neuroprotective and are determinant for neuronal survival. PDGF (platelet derived growth factor) is highly expressed in the white matter suggesting that PDGF may exert its function in white matter, participating either in the regeneration of damaged axons or in glial scar formation. Thus PDFG is likely to be angiogenic and neuroprotective in stroke ${ }^{22}$.

j. Acidosis - Experimental evidence indicates that glutamate receptors can be inactivated by extreme acidosis, in vitro, at least. In experimental studies, the combination of extracellular acidosis and glutamate-receptor antagonists provides greater neuronal protection than the glutamate receptor antagonist alone ${ }^{18}$.

1. Hypothermia can reduce the glutamate release and can be used as a neuroprotective action. Hyperthermia has an opposite effect ${ }^{23}$.

m. Potassium channel activators - Recent evidence suggests that activators of potassium channel on neurons, can have neuroprotective effects on neuronal ischemia and potential therapeutic implications. They maintain vascular responses of cerebral arterioles after infarction or hemorrhage. Probably these drugs may counteract ischemia depolarization by stimulating the efflux of potassium ions from cellular compartments, and consequently protect cerebral circulation ${ }^{24,25}$. Several drugs are under experimental tests.

\section{REFERENCES}

1. Choi DW. Methods for antagonizing glutamate neurotoxicity. Cerebrovasc Brain Metab Rev 1990;2:105-147

2. Greenamyre JT, Porter RHP. Anatomy and physiology of glutamate in the CNS. Neurology 1994;44(Suppl):S7-S13

3. Sette G, Toni D, De Michele M, et al. Pharmacotheraphy of stroke: an overview In Krieglstein J, Oberpichler-Schwenk H. Pharmacology of cerebral ischemia. Stuttgart Medpharm Scient Publ: 1994;605-610.

4. Jay TM- Neurotransmitter systems In Mraovitch S, Sercombe R. Neurophysiological basis of cerebral blood flow control: an introduction. London: John Libbley \& Co: 1996:63-87.

5. Olney JW, Ho OL, Rhee V. Cytotoxic effects of acidic and sulphur containing amino acids on the infant mouse central nervous system. Exp Brain Res 1971,14:61-76

6. Bucham AM. Do NMDA antagonists protect against cerebral ischemia: are clinical trials warrented? Cerebrovasc Brain Metab Rev 1990;2:1-26.

7. Hillend L, Hallstrom A, Segersvard S, Person L, Understedt U. Dynamics of extracellular metabolic in the striatum after middle cerebral artery occlusion in the rat, in monitored by intracerebral microdialysis. J Cereb Blood Flow Metab 1989;9:607-616.

8. Dávalos A, Castillo J, Serena J, Noya M. Duration of glutamate release after acute ischemic stroke. Stroke 1997,28:708-710.

9. Choi DW, Rothan SM. The glutamate neurotoxicity in hipoxic-ischemic neuronal death. Ann Rev Neurosc 1990;13:171182. 
10. Faraci F, Brian JE. Nitric oxide and the cerebral circulation. Stroke 1994;25:692-703.

11. Hossmann KA. Periinfarct Depolarizations. Cerebrosvasc brain Metab Rev 1996;8:195-208.

12. Grotta J. Lubeluzole treatment of acute ischemic stroke. Stroke 1997;28:2338-2346.

13. Sacchetti ML, Toni D, Fiorelli M, Argentino C, Fieschi C. The concept of combination therapy in acute ischemic stroke. Neurology 1997;49(Suppl):70-74.

14. Muir KW, Grosset DG. Neuroprotection for acute stroke making clinical trials work. Stroke 1999;30:180-182.

15. Grotta J. A Glimpse to the future: multitherapy trials. Cerebrovasc Dis 1995;5(Suppl):27-30.

16. Meldrum BS. The role of glutamate in epilepsy and other CNS Disorders. Neurology 1994;44(Suppl):14-23.

17. Calabresi P, Marfia GA, Centonze D, Pisani A, Bernardi G. Sodium influx plays a major role in the membrane depolarization induced by oxygen and glucose deprivation in rat striatal spiny neurons. Stroke 1999;30:171-179.

18. Gifford RG, Monyer H, Christine CW, Choi DW. Acidosis reduces NMDA receptor activation, glutamate neurotoxicity, and oxygen-glicose deprivation neuronal injury in cortical cultures. Brain Res 1990;506:339-342.

19. Choi DW. Editorial Comment. Stroke 1996; 27:2130

20. Flavin MP. Influence of dexamethasone on neurotoxicity caused by oxygen and glicose deprivation in vitro. J Neuropath Exp Neurol 1996;39:34-38.

21. Pringle AK, Benham CD, Sim L, Kennedy J, Iannotti F, Sundstrom LE. Selective N-type calcium channel antagonist omega conotoxin mviia is a neuroprotective against hypoxic neurodegeneration in organotypic hippocampal-slice cultures. Stroke 1996;27:2124-2130.

22. Krupinski J, Issa R, Bujny T, et al.. A Putative role for platelet-derived growth factor in angiogenesis and neuroprotection after ischemic stroke in humans. Stroke 1997;28:564-573.

23. Coimbra C, Drake M, Boris-Möller F, Wieloch T. Long-lasting neuroprotective effect of postischemic hypothermia and treatment with anti-inflammatory / antipyretic drug. Stroke 1996;27:1578-1585.

24. Veltkamp R. Domoki F, Bari F, Busija DW. Potassium channel activators protect the m-methil d-aspartate-induced cerebral vascular dilatation after combined hypoxia and ischemia in piglets. Stroke 1998;29:837-843.

25. Wei EP, Kontos HA, Beckmen JS- Antioxidants inhibit ATP-sensitive potassium channels in cerebral arterioles. Stroke 1998;29:817-823 